\title{
Exploring the construct of school readiness based on child development for kindergarten children
}

\author{
${ }^{*}{ }^{1}$ Farida Agus Setiawati; ${ }^{2}$ Rita Eka Izzaty; ${ }^{3}$ Agus Triyanto \\ *Faculty of Education, Universitas Negeri Yogyakarta \\ Jl. Colombo No. 1, Depok, Sleman 55281, Yogyakarta, Indonesia \\ *Email: farida_as@uny.ac.id
}

Submitted: 13 April 2017 | Revised:05 June 2017 | Accepted:06 June 2017

\begin{abstract}
Indonesian government has regulated that the basic age of readiness of a child to attend elementary schools is 7 years old. In fact, some children are not exactly 7 years old when they first go to school because they develop more rapidly. This study is aimed at investigating some aspects of child development which affect their readiness to attend elementary school. The subjects were 101 grade 1,2, and 3 teachers of elementary schools in Yogyakarta, a special Region in Indonesia. The data were collected through interviews. The results of the data collection were analyzed using both descriptive quantitative and qualitative techniques. The results of the study show some aspects of child development affecting their readiness to attend elementary schools, including: cognitive and language ability, social emotional skills, fine motor skills, gross motor skills, arts, religion and moral values, and some others. Beside these aspects, some problems in grades 1, 2, and 3 are also found. This study is expected to give significant indicators to create the construct of school readiness.
\end{abstract}

Keywords: school readiness, elementary schools, child development

\section{How to cite item:}

Setiawati, F., Izzaty, R., \& Triyanto, A. (2017). Exploring the construct of school readiness based on child development for kindergarten children. REiD (Research and Evaluation in Education), 3(1), 42-49. doi:http://dx.doi.org/10.21831/reid.v3i1.13663

\section{Introduction}

Elementary school admission is conducted every year. When kindergarten age children begin to attend elementary school, parents usually curious and frequently raise a question of what skills and capability their children must have to be considered as having school readiness.

The government has already regulated new student admission through Government Regulation No. 17 Year 2010 on educational management and implementation (2010) and Ministry of National Education (2011) regulation number 04/VI/PB/2011, consisting of national education regulations of new student admission in kindergarten or primary schools. This regulation says that the main indicator of new student admission is being 7 12 years old. However, some problems which arise are that many children who were born on certain months cannot be exactly 7 years old when the admission is conducted. Moreover, there are also some children who develop more rapidly in their age. Therefore, even though they are not exactly 7 years old, they have more rapid development at this age.

School readiness is a factor which plays the most important role for chidren to suceed in the learning process. School readiness consists of children's ability in various aspects that a human has, including emotion, cognition, language, social, and motor skills. The concept of school readiness has been widely 
defined and redefined by experts through various points of view. Some theories of child development and learning are employed to explain the meaning of school readiness. From some existing definitons, there are two types of meaning for readiness. The first meaning is studying readiness which consists of the description of children's readiness to be involved in learning physical material. The second is school readiness which consists of the description of capabilities from various aspects that human has, such as cognitive, language, social, and motor skills which are related to the curriculum which is used (Lewit \& Baker, 1995). Moreover, Dockett \& Perry (2002) add that chronological age must also be considered, because the finding of research indicates that chronological age has a positive correlation with the mental readiness and the development of each individual.

The National Association for the Education of Young Children in Dockett \& Perry (2002) states that in determining children's school readiness, the policy makers must consider these three aspects: (1) considering the children's existing experience, including skills or abilities possessed, in order to be able to predict whether children can be involved in learning activities in higher educational level or not. (2) Realizing individual differences in children, including the language and culture differences used. (3) Employing appropriate wishes and reasons of chidlren's ability which must be fullfilled as one of school readiness requirements.

From some cumpulsiary considered aspects, Technical Planning Group (in Dockett \& Perry, 2002), has identified some dimensions which become indicators in conducting an assessment of children's school readiness, including: (1) Motor development and physical condition; (2) Social and emotional development; (3) Learning approaches; (4) Language use; (5) Developmet of cognition and general knowledge.

Some experts have created instruments to detect learning readiness in elementary schools. Chew created an instrument named Lollipop test which measures school readiness (Lemelin \& Boivin, 2007). This instrument was created to detect children's school readi- ness in France. Some aspects which are measured by this test highly emphasize children's cognitive skills. Various indicators explained by this instrument include: (1) Color and shape identification; (2) Spatial recognition; (3) Number identification and calculation; (4) Letter identification and writing system. These four development indicators are given to children in the form of an interview or an oral test.

Another instrument developed to detect children's school readiness is Early Development Instrument (EDI). This instrument was developed by Janus et al. (2006). This test reveals some areas of child development, including: (1) physical health and well-being, (2) social competence anf emotional maturity, (3) language and cognitive development, (4) communication and general skills.

In Indonesia, the Minister of National Education has created some standards to be applied for early childhood education. The standards are accommodated by the Ministry of National Education (2014) in the minister regulation number 137 year 2014. One of the standards included in this regulation is standard 1. This standard contains basic task of development, which must be taught to children in each development stage. At the end of early childhood, or age 5-6, some of the developmental characteristics which have been possessed are: (1) Religious and moral values; (2) Physical-motor skills, including gross motor skill, fine motor skill, health and safety behavior; (3) Cognitive, including learning and problem solving, logical and symbolic thinking; (4) Language skill, including language comprehension, language expression skills, and literacy; (5) Social-emotional, consisting of self-awareness, sense of responsibility to self and others, and also pro-social behaviors; (6) Arts, consisting of children's ability to enjoy various songs, melodies, or voices, and interest in art activities.

The regulation shows that there are various dimensions or aspects that have to be taught to early children. Those various aspects have become comptencies which are expected to appear in 5-6 year-old children. However, among those afore-mentioned aspects, the extent aspect which has a significant role in 
preparing school readiness has not been revealed yet. Therefore, it is crucial to identify the aspects which contribute to preparing children's school readiness. If certain aspects do not appear or are not in children's characters, then there will be a lot of problems which have to be encountered by children while studying in elementary schools.

The afore-mentioned explanation also portrays the existence of differences which underlie school readiness. For instance, the opinion of Dockett \& Perry (2002) is different to Lemelin \& Boivin (2007). This difference is affected by teacher and expert perceptions in determining the developmental aspects which underlie children's school readiness. In addition, the situation, condition, and culture of learning processes also influence general readiness. Therefore, examining the aspects which affect school readiness based on distinctive characteristics of a region is significant. Thus, two research questions for the first year of this research are proposed: (1) What are the developmental aspects which affect children's school readiness in elementary schools in Indonesia? (2) What are the problems related to children's lack of readiness to attend elementary schools?

\section{Method}

This research is qualitative and quantitative research. The type of the research in this first year is exploratory and that in the second year is developmental.

The subject of this research was 101 elementary school teachers of early grades from and four districts in Yogyakarta Special Region, including Bantul, Sleman, Kulonprogo, and also Yogyakarta municipality. The data collecting technique which was used in this research was snowball sampling technique. This technique was based on the previous sample investigation. The investigations began with the key person of elementary teacher group, or Kelompok Kerja Guru (KKG) in Indonesian language, board management. They were asked to select some teachers in each elementary school. After identifying the teachers, the researchers interviewed them by phone.
This research was a survey which was aimed at revealing the developmental aspects which affect children's readiness to attend elementary schools. In collecting the data, the researchers employed an interview technique with the assistance of interview guidelines, and the questions about the aspects of school readiness and the problems of the students who were not ready yet to attend elementary school. The interview results were identified, and the collected information was coded and extracted. Therefore, the data revealed some developmental aspects which played important roles in the children's school readiness. In analyzing the data, descriptive analysis technique was employed. The revealed data were analyzed by percentace of subjects' responses.

\section{Findings and Discussion}

\section{Aspects of School Readiness}

The findings of extracted data reveal some factors or dimensions which underlie children's learning readiness to attend elementary schools. The findings are presented in Table 1.

Based on Table 1, there are 29 child performances which influence school readiness. Of the 29 aspects, the five most influential aspects are concentration (15\%), imitating movements (running, jumping, standing on one leg) and dancing (9.82\%), team work $(9.22 \%)$, recognizing letters $(8.62 \%)$, and also reading/comprehending reading texts (7.21). On the other hand, the five lowest aspects are obeying the rules/discipline $(0.4 \%)$, drawing curves, straight lines, circles, as well as squares $(0.4 \%)$, religious activities (praying, charity) $(0.2 \%)$, sharing/helping others $(0.2 \%)$ and creativity $(0.2 \%)$.

The result shown in Table 1 is child performances which influence readiness. The performances are classified into six developmental aspects in the activity programs of kindergartens: cognitive, social emotional, and fine motor skills; gross motor skills; fine motor skills; art; religion and moral; and other aspects. 
Table 1. Child performance which influences school readiness

\begin{tabular}{|c|c|c|}
\hline $\begin{array}{c}\text { Child } \\
\text { Performances }\end{array}$ & $\begin{array}{c}\text { Data } \\
\text { Finding } \\
(\%)\end{array}$ & $\begin{array}{c}\text { Aspects of } \\
\text { Development }\end{array}$ \\
\hline Concentration & 15 & Other Factors \\
\hline $\begin{array}{l}\text { Imitating } \\
\text { movements } \\
\text { (running, jumping) }\end{array}$ & 9.82 & Gross Motor \\
\hline Team work & 9.22 & Social Emotional \\
\hline Recognizing letters & 8.62 & Cognitive \\
\hline $\begin{array}{l}\text { Reading/comprehen } \\
\text { ding reading texts }\end{array}$ & 7.21 & Cognitive \\
\hline $\begin{array}{l}\text { Recognizing } \\
\text { numbers }\end{array}$ & 6.81 & Cognitive \\
\hline $\begin{array}{l}\text { Parents (caring, } \\
\text { breakfast, children's } \\
\text { readiness) }\end{array}$ & 5.61 & Other Factors \\
\hline $\begin{array}{l}\text { Socialization with } \\
\text { peers }\end{array}$ & 4.61 & Social Emotional \\
\hline $\begin{array}{l}\text { Classroom } \\
\text { adaptation }\end{array}$ & 4.21 & Social Emotional \\
\hline $\begin{array}{l}\text { Fine motor } \\
\text { (snipping and } \\
\text { sticking) }\end{array}$ & 4.21 & Fine Motor \\
\hline Vocabulary & 3.81 & Language \\
\hline Writing & 3.41 & Fine Motor skills \\
\hline $\begin{array}{l}\text { Following rhythms, } \\
\text { sounds, and tones }\end{array}$ & 2.81 & Art \\
\hline Story telling & 2.2 & Language \\
\hline Independence & 2 & Social Emotional \\
\hline $\begin{array}{l}\text { Apprehending the } \\
\text { rules }\end{array}$ & 1.6 & Social Emotional \\
\hline Age & 1.4 & Other Factors \\
\hline $\begin{array}{l}\text { Apprehending } \\
\text { instruction and } \\
\text { information }\end{array}$ & 1.2 & Cognitive \\
\hline Counting & 1 & Cognitive \\
\hline Fluent speaking & 1 & Language \\
\hline Problem solving & 0.8 & Cognitive \\
\hline Drawing & 0.8 & Art \\
\hline Holding stationery & 0.6 & Fine Motor skills \\
\hline $\begin{array}{l}\text { Recognizing colors } \\
\text { and their uses }\end{array}$ & 0.6 & Cognitive \\
\hline $\begin{array}{l}\text { Obeying rules/ } \\
\text { discipline }\end{array}$ & 0.4 & Social Emotional \\
\hline $\begin{array}{l}\text { Drawing curves, } \\
\text { straight lines, circles, } \\
\text { and squares }\end{array}$ & 0.4 & Fine Motor skills \\
\hline $\begin{array}{l}\text { Religious activities } \\
\text { (praying, reading } \mathrm{Al} \\
\text { Quran, charity) }\end{array}$ & 0.2 & $\begin{array}{l}\text { Religious and } \\
\text { Moral Values }\end{array}$ \\
\hline $\begin{array}{l}\text { Sharing/helping } \\
\text { others }\end{array}$ & 0.2 & Social Emotional \\
\hline Creativity & 0.2 & Art \\
\hline
\end{tabular}

Table 2. Child performances on cognitive which influence school readiness

\begin{tabular}{lc}
\hline \multicolumn{1}{c}{ Child Performances } & $\mathbf{\%}$ \\
\hline Reading/comprehending reading texts & 7.2 \\
Recognizing numbers & 6.8 \\
Recognizing letters & 8.6 \\
Counting & 1.0 \\
Vocabulary building & 3.8 \\
Apprehending instruction and & 1.2 \\
information & \\
Story telling & 2.2 \\
Fluent speaking & 1.0 \\
Problem solving & 0.8 \\
Recognizing colors and their usage & 0.6 \\
\hline \multicolumn{2}{c}{ Sum } \\
\hline
\end{tabular}

Based on Table 2, there are 10 cognitive child performances. The three highest cognitive performances of school readiness are recognizing letters $(8.6 \%)$, reading/comprehending texts $(7.2 \%)$, and recognizing numbers $(6.8 \%)$. The following cognitive aspects are vocabulary building $(3.8 \%)$, story-telling $(2.2 \%)$, comprehending instructors, and information $(1.2 \%)$, and fluent speaking, and also counting. The two lowest ranks are problem solving $(0.8 \%)$ and recognizing colors $(0.6 \%)$.

Table 3. Child performances of children's readiness based on social emotional aspects

\begin{tabular}{clc}
\hline No. & \multicolumn{1}{c}{$\begin{array}{c}\text { Social Emotional } \\
\text { Performances }\end{array}$} & $\mathbf{\%}$ \\
\hline 1. & Team work & 9.2 \\
2. & Socialization with peers & 4.6 \\
3. & Classroom adaptation & 4.2 \\
4. & Independence & 2.0 \\
5. & Obeying rules / discipline & 2.0 \\
6. & Sharing/helping others & 0.2 \\
\hline \multicolumn{2}{c}{ Sum }
\end{tabular}

Table 3 shows that there are six child performances of school readiness based on social emotional aspects. The highest performance is team work $(9.2 \%)$, the second rank is socialization with peers $(4.6 \%)$ followed by classroom adaptation (4.2\%), independence $(2.0 \%)$, and obeying rules/discipline $(2.0 \%)$. Meanwhile, the lowest rank is sharing/helping others $(0.2 \%)$. 
Table 4. Child performances of fine motor skills children's which influence school readiness

\begin{tabular}{ll}
\hline $\begin{array}{c}\text { Performance of Fine } \\
\text { Motor Skills }\end{array}$ & $\mathbf{\%}$ \\
\hline Cutting and pasting & 4.2 \\
Writing & 3.4 \\
Holding stationery & 0.6 \\
Drawing curves, straight & 0.4 \\
lines, circles, and squares & \\
\hline \multicolumn{1}{c}{ Sum } & 8.6 \\
\hline
\end{tabular}

Table 4 shows that there are four child performances of school readiness based on fine motor skills, including cutting and pasting, writing, holding stationery, drawing some curves, straight lines, and also squares. The other motoric skills are gross motor skill (see Table 5), which has only one aspect, namely: imitating movements (including running, jumping, standing on one leg) or dancing $(9.8 \%)$, and this aspect becomes the second highest aspect.

Table 5. The performance of school readiness based on gross motor skills

\begin{tabular}{clc}
\hline No. & $\begin{array}{c}\text { Performances of Gross } \\
\text { Motor Skills }\end{array}$ & $\%$ \\
\hline 1. & $\begin{array}{l}\text { Imitating movements } \\
\text { (running, jumping, standing } \\
\text { on one leg) or dancing }\end{array}$ & 9.8 \\
\hline
\end{tabular}

Table 6. Child performances of school readiness based on art

\begin{tabular}{clc}
\hline No. & \multicolumn{1}{c}{ Child Performances of Art } & $\mathbf{0}$ \\
\hline 1. & Following rhythms, sounds, and tones & 2.8 \\
2. & Drawing & 0.8 \\
3. & Creativity & 0.2 \\
\hline \multicolumn{2}{c}{ Sum } & 4.8 \\
\hline
\end{tabular}

The art aspect is divided into three points (as presented in Table 6). The highest is following rhythm, sounds, and tones $(2.8 \%)$, followed by drawing $(0.8 \%)$ and then creativity $(0.2 \%)$.

Table 7. Child performances of school readiness based on religion and moral

\begin{tabular}{lc}
\hline \multicolumn{1}{c}{ Religion and Moral Performance } & $\mathbf{\%}$ \\
\hline $\begin{array}{l}\text { Religious activities (praying, reading Al } \\
\text { Quran, charity) }\end{array}$ & 0.2 \\
\hline
\end{tabular}

As presented in Table 7, the next aspect is that of religion and morality which consists of religious activities $(0.2 \%)$. Such phenomenon needs further identification because religion and moral aspect, which is one of the aspects of school readiness, has the lowest percentage among the other influential aspects.

Table 8. Child performances of school readiness based on other aspects

\begin{tabular}{lc}
\hline \multicolumn{1}{c}{ Other Performance } & $\mathbf{\%}$ \\
\hline Concentration & 15.0 \\
Parents' Caring & 5.6 \\
Age & 1.4 \\
\hline \multicolumn{2}{c}{ Sum } \\
\hline
\end{tabular}

The last aspect of school readiness as presented in Table 8 is dealing with other aspects which are not appropriately categorized into one of the existing aspects of development. This category is divided into three parts, namely concentration (15\%), parents' caring $(5.6 \%)$, and age $(1.4 \%)$. The three aspects give great contribution, especially the aspects of concentration and parents' caring. In fact, the most important requirement of student admission in Indonesia is age. Therefore, the role of the other aspects, in particular concentration and parents' caring, must also be considered.

The findings show a number of developmental aspects which contribute to children's learning readiness to attend elementary school. In terms of roles, ordered from the most to the least dominant, the roles are cognitive, social-emotional, other (concentration, parents' caring, and age), gross motor skills, fine motor skills, religion, and moral aspects. Those aspects will be used as a draft for developing the construct instruments of school readiness in elementary school.

Finding Aspects of School Readiness Learning Problems of Early Grade Students

There are many problems extracted by the data related to children's lack of readiness to attend elementary schools which emerge in Yogyakarta. Table 9 shows that there are 26 aspects of learning problems faced by early grade students. 
Table 9. Learning problems of lower grade students

\begin{tabular}{clc}
\hline No. & \multicolumn{1}{c}{ General Description } & $\mathbf{\%}$ \\
\hline 1. & Children's focusing on playing & 15.4 \\
2. & Hard to follow the rule & 10.5 \\
3. & Daydreaming & 9.37 \\
4. & Stop studying & 7.44 \\
5. & Low learning result & 6.34 \\
6. & Slow task working & 5.23 \\
7. & Disturbing friends & 4.41 \\
8. & Slow instruction comprehending & 4.41 \\
9. & Being timid/afraid of asking & 4.41 \\
10. & Exiting class & 4.41 \\
11. & Wandering/running around the & 4.13 \\
& classroom & \\
12. & Asking to be waited by parents & 3.58 \\
13. & Being unconfident & 3.58 \\
14. & Story telling/cheating with friends & 3.31 \\
15. & Lackluster & 2.48 \\
16. & Crying & 2.2 \\
17. & Dependence on teacher & 2.2 \\
18. & Keeping silent & 1.65 \\
19. & Feeling bored & 1.38 \\
20. & Easily exhausted & 1.1 \\
21. & Not completing the task & 0.83 \\
22. & Frequently asking for going home & 0.83 \\
23. & Not doing homework & 0.28 \\
24. & Moving around/Not sitting still & 0.28 \\
25. & Being alone/isolated & 0.28 \\
\hline & & \\
\hline
\end{tabular}

Table 9 shows that learning problems are always found in each educational level, and thus, some efforts to solve these problems are highly needed. Through the interview which had been conducted, this research identifies many problems faced by the first up to third graders of elementary school.

Table 10 explains the various learning problems encountered by grade 1, 2, and 3 students of elementary school. It also shows that the higher the grade, the fewer the problems will be. However, it is also clearly shown that the problems faced by students of grade 1,2 , and 3 are identical. Their problems are in terms of motivation, learning, independence, concentration, interaction, liveliness, motor skills, and comprehension. Meanwhile, the problems shared by each grade related to learning problems are stopping learning, not completing the task, not doing assignment/ homework, daydreaming, keeping silent, and slowness in comprehending in-struction. The similar problems possessed by grade 1 and 2 students are frequently asking to go home. In addition, other common problems encounter- ed by elementary school students are feeling bored, lackluster performance, slowness in comprehending instruction, and not sitting still. Through in-depth identification, it is clearly shown that the problems related to social-emotional aspects more commonly occur than cognitive aspects. This condition is in line with the previous research findings which reveal that one of the aspects influencing children's learning readiness is social and emotional aspects. Therefore, social and emotional aspects determine children's learning readiness.

Table 10. Learning problems of students of grades 1, 2 and 3 of elementary school

\begin{tabular}{|c|c|c|c|}
\hline Learning Problem & $\begin{array}{c}\text { Grade } \\
1\end{array}$ & $\begin{array}{c}\text { Grade } \\
2\end{array}$ & $\begin{array}{c}\text { Grade } \\
3\end{array}$ \\
\hline Stop studying & $\checkmark$ & $\checkmark$ & $\checkmark$ \\
\hline $\begin{array}{l}\text { Not completing the } \\
\text { task }\end{array}$ & $\checkmark$ & $\checkmark$ & $\checkmark$ \\
\hline Slow task working & $\checkmark$ & $\checkmark$ & $\checkmark$ \\
\hline $\begin{array}{l}\text { Not doing } \\
\text { assignment/homework }\end{array}$ & $\checkmark$ & $\checkmark$ & $\checkmark$ \\
\hline Low learning result & $\checkmark$ & $\checkmark$ & $\checkmark$ \\
\hline $\begin{array}{l}\text { Asking to be waited by } \\
\text { parents }\end{array}$ & $\checkmark$ & $\checkmark$ & $\checkmark$ \\
\hline Being not dependent & $\checkmark$ & $\checkmark$ & $\checkmark$ \\
\hline Hard to follow the rules & $\checkmark$ & $\checkmark$ & $\checkmark$ \\
\hline Crying & $\checkmark$ & $\checkmark$ & $\checkmark$ \\
\hline Children focus on play & $\checkmark$ & $\checkmark$ & $\checkmark$ \\
\hline $\begin{array}{l}\text { Story telling/cheating } \\
\text { with friends }\end{array}$ & $\checkmark$ & $\checkmark$ & $\checkmark$ \\
\hline $\begin{array}{l}\text { Wandering/running } \\
\text { around the classroom }\end{array}$ & $\checkmark$ & $\checkmark$ & $\checkmark$ \\
\hline Daydreaming & $\checkmark$ & $\checkmark$ & $\checkmark$ \\
\hline Disturbing friends & $\checkmark$ & $\checkmark$ & $\checkmark$ \\
\hline Keeping silent & $\checkmark$ & $\checkmark$ & $\checkmark$ \\
\hline Easily exhausted & $\checkmark$ & $\checkmark$ & $\checkmark$ \\
\hline $\begin{array}{l}\text { Moving around/ Not } \\
\text { sitting still }\end{array}$ & $\checkmark$ & $\checkmark$ & $\checkmark$ \\
\hline $\begin{array}{l}\text { Frequently asking for } \\
\text { going home }\end{array}$ & $\checkmark$ & & \\
\hline Dependence on teacher & $\checkmark$ & & \\
\hline Exiting class & $\checkmark$ & & \\
\hline Feeling bored & $\checkmark$ & & \\
\hline Lackluster behavior & $\checkmark$ & & \\
\hline $\begin{array}{l}\text { Slow instruction } \\
\text { comprehension }\end{array}$ & & $\checkmark$ & $\checkmark$ \\
\hline
\end{tabular}

\section{Conclusion and Suggestions}

The findings of this research show that there are some performing developmental aspects influencing children's learning readiness to attend elementary school. Ordered from the most to the least dominant, the effects are 
explained as follows: (1) cognitive and language aspects, consisting of recognizing letters, reading, recognizing numbers, counting, vocabulary building, comprehending instruction and information, fluent speaking, story telling, and problem solving; (2) social emotional aspects, consisting of team work, socialization with peers, classroom adaptation, independence, apprehending rules, discipline, helping others; (3) other aspects, consisting of concentration, parents' caring, and age; (4) fine motor skills aspects, consisting of writing, snipping and sticking, holding stationeries, and drawing lines; (5) gross motor skills aspects consisting of imitating movements (running, jumping, and standing on one leg) or dancing; (6) arts, consisting of memorizing poem, drawing, and creativity; and (7) religion and other moral aspects, which consist of religious activities such as praying, reading Holy Quran, and charity.

Parents' caring played great role in preparing their children to go to school. Parental style and involvement at school and at home give big influences on the academic success of their children (Magdalena, 2014). Also, the parental characteristics and practices affect children's success. Furthermore, Tunçeli and Akman (2013) found that parents' age and education affect the school readiness of their child.

In addition to the afore-mentioned aspects, this research also finds some problems faced by elementary school students of grade 1,2 , and 3 . The most dominant problems are related to socio-emotional, such as children focus on playing, hard to follow the rule, and stopping studying. Therefore, socialemotional aspects highly determine the readiness of children to attend elementary school compared to other aspects.

Based on the research findings, the following suggestions are proposed: (1) Children's learning readiness to attend elementary school is affected not only by age, but also by other developmental aspects which play significant roles in determining readiness. Therefore, identifying some aspects to construct the component of school readiness is needed. (2) Moreover, cognitive aspects, social-emotional aspects, concentration, as well as parental caring also play a big role to determe children's learning readiness to attend elementary school. Therefore, teachers, educators, or psychologists need to give special considerations to these aspects. Such action contributes to easily decide children's learning readiness to attend elementary school, especially those who do not meet the age requirement. (3) For instrument developers, the findings of this research need to be followed up by composing new instruments which can detect some appropriate indicators of school readiness and are not only oriented to cognitive aspects and fine motor skills, but also social-emotional aspects, concentration, parents' caring, age, gross motor skills, and arts.

This research was focused only on many aspects of child development. Meanwhile the roles of environment factors are not considered yet though many researchers have studied the role of environment on students' school readiness. Shaari \& Ahmad (2016) found that physical and social environment have effect on school readiness. The environment has indirect effect on stimulating many aspects of child development.

\section{References}

Dockett, S., \& Perry, B. (2002). Who's ready for what? Young children starting school. Contemporary Issues in Early Childhood, 3(1), 67-89. https://doi.org/10.2304/ciec.2002.3.1.9

Government Regulation No. 17 Year 2010 on educational management and implementation (2010). Indonesia.

Janus, M., Brinkman, S., Duku, E., Hertzman, C., Santos, R., Sayers, M., ... Walsh, C. (2006). The early development instrument: $A$ population-based measure for communities. $A$ handbook on development, properties, and use. Ontario: Offord Centre for Child Studies.

Lemelin, J.-P., \& Boivin, M. (2007). Success starts in grade 1: The importance of school readiness. Québec Longitudinal Study of Child Development, 4(2), 1-12.

Lewit, E. M., \& Baker, L. S. (1995). School readiness. The Future of Children, 5(2), 
128-139.

https://doi.org/10.2307/1602361

Magdalena, S. M. (2014). The effects of parental influences and school readiness of the child. Procedia - Social and Behavioral Sciences, 127, 733-737.

https://doi.org/10.1016/j.sbspro.2014.0 3.345

Ministry of National Education. Minister regulation no. 04/VI/PB/2011 on student admission at kindergarten/raudhatul athfal/bustanul athfal and school/madrasah (2011).

Ministry of National Education. Minister regulation no. 137 year 2014 on the national standard of early childhood education (2014).

Shaari, M. F., \& Ahmad, S. S. (2016). Physical learning environment: Impact on children school readiness in Malaysian preschools. Procedia - Social and Behavioral Sciences, 222, 9-18.

https://doi.org/10.1016/j.sbspro.2016.0 5.164

Tunçeli, H. I., \& Akman, B. (2013). The investigation of school readiness level of six years old preschool children in terms of different variables. Procedia - Social and Behavioral Sciences, 106, 2899-2905. https://doi.org/10.1016/j.sbspro.2013.1 2.335 